\title{
PENGEMBANGAN EKOWISATA PULAU TUNDA BERBASIS KOMUNITAS DALAM ERA INDUSTRI 4.0
}

\author{
Helmy Faizi Bahrul Ulumi('), Muhammad Syafar $\left({ }^{*}\right)$ \\ 12 Department of Islamic Community Development, State Islamic University of Sultan Maulana Hasanuddin Banten, Indonesia.
}

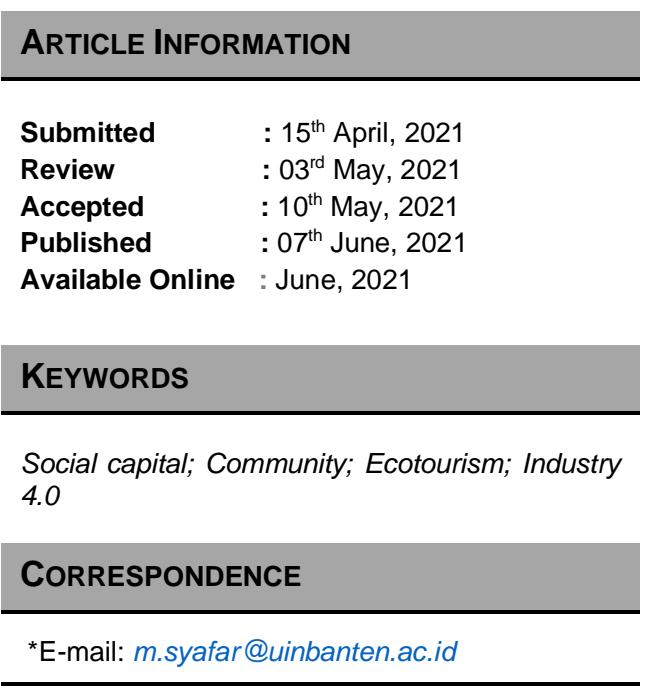

\begin{abstract}
A B S T R A C T
The development agenda that designed in the Sustainable Development Goals (SDGs) in 2030 is a challenge for all global stakeholders. This article aims: 1) To identify ecotourism that is develop based on the social capital and local wisdom of community in Tunda Island, 2) To identify the development of community-based ecotourism in the industrial era 4.0 through digital technology, 3) To analyse of benefits of digital technology for ecotourism development. The method used through field study with descriptive qualitative research type. The results of the study show that are: 1) ecotourism that has been developed by the community focuses on social capital and local wisdom of the community, 2) Digital technology application on the implementation of ecotourism development conducted through the provision of websites and social media by community of Tunda island, and 3) Benefit of digital technology has an impact for socioeconomic of community and acessability dealing with ecotourism management. Furthermore, enhaching human capacity needed for community to improve Tourism Group (Pokdarwis) as a social institution that has a role in developing ecotourism in Tunda Island.
\end{abstract}

\section{A. PENDAHULUAN}

$\mathrm{P}$ ulau Tunda terletak di desa Wargasara yang merupakan salah satu gugusan pulau di Serang, Banten. Pulau ini jaraknya sekitar 18 mil dari pelabuhan Karangantu, pulau ini memiliki luas \pm 260 hektar yang di dalamnya memiliki potensi sumberdaya yang unik, terdiri dari: sosial, laut dan pesisir dan pertanian yang memiliki manfaat bagi penduduk. Sebagaimana yang dikemukanan Umam (2019: 14) bahwa Pulau Tunda memiliki potensi alam, berupa laut yang cukup luas dan garis pantai dengan pasir putihnya, keindahan biota bawah laut dengan berbagai macam jenis ikan hias, terumbu karang dan lamun, di bagian kampung timur terdapat hutan Mangrove yang sebagian potensinya masih belum diperkenalkan sebagai ekowisata bahari bagi wisatawan.

Wisata bisa diartikan sebagai aktivitas berkunjung sesorang ke tempat tujuan untuk rekreasi, menghabiskan waktu untuk memenuhi rasa ingin tahu di waktu libur maupun senggang. Dalam Undang-undang (UU) Nomor 10 tahun 2009 tentang Kepariwisataan, yang dimaksud dengan pariwisata adalah berbagai macam kegiatan wisata yang didukung oleh berbagai fasilitas serta layanan yang disediakan masyarakat, pengusaha, Pemerintah dan Pemerintah Daerah. Jadi wisata merupakan upaya seseorang untuk berkunjung dalam mengisi waktu senggangnya dengan tujuan dapat memperoleh manfaat dari berbagai fasilitas dan layanan yang tersedia.

Konsep ekowisata sangat melekat dengan alam dan manusia. Manusia yang tinggal di lingkungan alam yang indah memiliki tanggung jawab untuk melestarikannya untuk memberikan manfaat bagi manusia lainnya, termasuk memberikan pelayanan wisata tanpa merusak lingkungan alamnya. Ekowisata 
ekowisata didefinisikan The International Ecotourism Society (TIES) dalam Hijriati (2014) sebagai perjalanan wisata alam yang bertanggung jawab terhadap lingkungan dan meningkatkan kesejah teraan masyarakat lokal. Dalam pengembangan ekowisata sangat penting peran modal sosial komunitas sebagai aset yang memegang peranan penting untuk menjaga keberlanjutan sosial ekonomi lingkungan.

Potensi alam yang indah dan lestari tersebut ternyata belum didukung oleh sumberdaya sosial dalam memanfaatkan alam sebagai sumber peningkatan ekonomi masyarakat. Pulau tunda memiliki potensi wisata berbasis sumberdaya pesisir dan lautan yang mampu berkontribusi bagi tumbuhnya peluang ekonomi lokal, namun saat ini pengembangannya masih relatif terbatas. Namun Sulistian (2016: vi) menyebut di Pulau Tunda memiliki kelemahan berupa kualitas sumberdaya manusia dan sadar wisata yang rendah serta permasalahan sampah yang berada di pesisir Pulau Tunda, serta ancaman kerusakan taman bawah laut yang dapat menghambat kelestarian lingkungan bagi pengembangan wisata berbasis sumberdaya lokal.

Pulau Tunda yang menyimpan keindahan potensi sumberdaya alam yang sangat menarik, serta memiliki ekosistem lautan dan pesisir yang kompleks tersebut ternyata juga di akui oleh berbagai peneliti sains dan sosial yang mengkaji Pulau Tunda (Kuswara, 2013; Syahrial \& Sastriawan, 2018; Zamani, 2016). Namun kelestarian sumberdaya alam di pulau ini belum dikembangkan oleh program wisata yang saat ini sedang dikelola oleh komunitas lokal. Pengelolaan wisata tersebut juga belum didukung oleh sumberdaya manusia (SDM) yang fokus pada peningkatan pelayanan wisata berbasis kelestarian alam dan penggunaan teknologi digital sebagai sarana promosi wisata. Padahal pengelolaan wisata di era millenial bertumpu pada kekuatan teknologi informasi di era industri 4.0 sebagai sarana promosi wisata, dimana setiap wisatawan yang ingin menikmati wisata pulau tunda memperoleh informasi sehingga mereka ingin berkunjung ke pulau ini. Bagi wisatawan yang berkunjung ke Pulau Tunda, menurut Darus, dkk (2014) mencatat bahwa wisatawan dapat menikmati 3 (tiga) ekosistem pesisir penting, diantaranya: ekosistem mangrove, lamun dan terumbu karang.

Pengembangan ekowisata di Pulau Tunda berbasis komunitas tentu akan memberikan pengaruh terhadap kehidupan masyarakat lokal. Pengelolaan ekowisata berbasis masyarakat di Pulau Tunda secara manfaat akan memberikan kontribusi secara signifikan terhadap ekologi, sosial dan ekonomi komunitas tersebut. Pendekatan pengembangan ekowisata ini bertumpu pada sumberdaya lokal, baik alam maupun sosial untuk menciptakan ekonomi keberlanjutan, yang tidak hanya mengejar profit sesaat dan kelestarian ekologi akan terancam di masa depan. Untuk itu, pemanfaatan tekonologi informasi dalam mempromosikan ekowisata di era industri 4.0 diarahkan untuk mengedepankan aspek kelestarian lingkungan dalam upaya menciptakan ekonomi komunitas yang berkelanjutan. Para wisatawan bisa menikmati keindahan pulau tunda dengan sarana yang disediakan oleh komunitas, dan juga tetap bersamasama menjaga kelestarian lingkungan. Untuk itu, artikel ini membahas: 1) potensi modal sosial yang ada Pulau Tunda dalam pengembangan ekowisata berbasis komunitas, 2) penggunaan teknologi informasi sebagai sarana promosi ekowisata Pulau Tunda di era industri 4.0, dan 3) menganalisis manfaat teknologi informasi melalui webiste dalam mempromosikan ekowisata Pulau Tunda.

Pengembangan ekowisata perlu mengedepankan aspek kelestarian lingkungan. Komunitas di Pulau Tunda merupakan penduduk yang sudah lama mendiami pulau ini dan menjadikannya sebagai sumber penghidupan. Dalam kajian ini, ekowisata diarahkan pada peningkatan ekonomi berbasis lingkungan dan mendukung konservasi, serta pengelolaannya mendukung berbagai aspek sosial, ekonomi, budaya dan teknologi informasi. Komunitas memiliki modal sosial yang mampu mendukung pengembangan penghidupannya ke arah yang lebih baik, sehingga identifikasi modal sosial komunitas Pulau Tunda sangat penting dilakukan untuk memperoleh gambaran yang utuh dalam pengembangan ekowisata berbasis komunitas ini di era millenial. Kemudian, peran website sebagai sarana tekonologi informasi dalam mendukung promosi wisata Pulau Tunda juga penting diintervensi untuk mengetahui manfaat yang bisa berkontribusi komunitas dan wisatawan. Komunitas millenial yang saat ini di dominasi oleh pemuda di Pulau Tunda memegang peranan penting dalam mempromosikan ekowisata di wilayahnya kepada publik, sehingga pondasi sosial ekonomi dapat diperkuat oleh komunitas tanpa mengancam kerusakan lingkungan yang membayakan penghidupan mereka di masa yang akan datang.

\section{B. METODE PENELITIAN}

$\mathrm{P}$ engembangan ekowisata yang telah dilakukan oleh komunitas Pulau Tunda setidaknya sudah memberikan manfaat walaupun belum berdampak secara luas, khususnya Provinsi Banten. 
Usaha yang dilakukan ini digerakkan oleh Kelompok Pemuda yang tergabung dalam Kelompok Sadar Wisata (Pokdarwis) dalam naungan Karang Taruna dan Pemerintah Desa. Pokdarwis ini terdiri dari keanggotaan yang memiliki tujuan bersama, yaitu memanfaatkan sumberdaya alam lokal untuk kesejahteraan bersama, namun ada juga tokoh masyarakat yang berpatisipasi menjadi anggota Pokdarwis. Dengan demikian, Pokdarwis yang telah terbentuk secara social ekonomi mampu memberikan pelayanan dan secara bisnis dikembangkan oleh pemuda.

Atas dasar penjelasan di atas, Pulau Tunda yang terletak di desa Wargasara, kecamatan Tirtayasa, kabupaten Serang dipilih sebagai lokasi studi yang merupakan wilayah yang memiliki potensi pengembangan ekowisata untuk pembangunan pedesaan melalui kewirausahaan yang digerakkan oleh pemuda lokal. Saat ini Pokdarwis hanya sebatas menjalan program wisata sederhana melalui pola Tour Guide padahal wilayah ini pada umumnya banyak usaha produktif yang bisa dilakukan pada sektor industri kecil termasuk industri rumah tangga (usaha mikro, kecil dan menengah), seperti : industri kerajinan lokal. Disamping itu, wilayah ini memiliki potensi sumberdaya alam (pertanian \& perikanan) sebagai sumber penghidupan masyarakat pedesaan melalui pengembangan ekowisata berbasis komunitas.

Dari segi tujuannya, penelitian ini merupakan studi deskriptif-analitik yang digunakan untuk mendapatkan gambaran secara sistematis, faktual dan akurat mengenai fakta-fakta hubungan antara fenomena yang sedang diselidiki. Menurut Sugiyono (2008: 105) studi deskriptif-analitik didefinisikan sebagai studi yang dilakukan dengan cara mengumpulkan data dan informasi sesuai dengan kondisi yang sebenarnya kemudian data-data tersebut disusun, diolah dan dianalisis untuk dapat memberikan gambaran mengenai masalah yang ada.

Definisi di atas menjelaskan bahwa jenis studi ini tidak dapat dilepaskan dan sangat terkait dengan proses studi deskriptif yang dilakukan untuk mengumpulkan informasi mengenai suatu gejala yang ada dalam kondisi yang sebenarnya pada saat studi berlangsung. Mengutip penjelasan dari Neuman (Neuman, 2000: 21-22) bahwa "Descriptive research presents a picture of the specific details of the situation, social setting, or relationship." (Studi deskriptif menyajikan suatu gambaran detail yang spesifik dari situasi, seting sosial, atau hubungan). Kemudian data dan informasi tersebut disusun, diolah serta dianalisa secara mendalam yang bertujuan memberikan gambaran lengkap mengenai gejala atau fenomena yang terjadi apa adanya. Jadi, proses yang dilakukan dalam jenis studi ini yaitu proses deskripsi dan analisa.

Dalam penentuan informan dilakukan secara selektif. Informan yang dipilih dalam studi kualitatif perlu memiliki informasi yang cukup mengenai fenomena yang akan diteliti sehingga peneliti dapat memahami mengenai fenomena yang terjadi berkaitan dengan objek studi. Neuman (2003: 394) menjelaskan bahwa narasumber yang baik memiliki karakteristik (The ideal informant has four characteristic) sebagai berikut ini: a) The informant is totally familiar with the culture and is position to witness significant events makes a good informant; b) The individual is currently involved in the field; c) The person can spend time with the researcher, and; d) Non analytic individuals make better informants. A non analytic informant is familiar with and uses native folk theory or pragmatic common sense.

Atas penjelasan tersebut bahwa pemilihan informan yang ditentukan yaitu mereka telah mengenal dengan baik kondisi sosial budaya lokal dan merupakan saksi mata terhadap kejadian yang terjadi, informan merupakan pihak yang terlibat langsung di lapangan, informan tersebut dapat menghabiskan waktu bersama dengan peneliti, dan informan tidak bersifat analitis.

Sesuai dengan karakteristik sumber data dan informasi, teknik pengumpulan data yang digunakan, yaitu: 1) Studi literatur, dilakukan untuk memperoleh data sekunder yakni dengan mempelajari dan mengkaji sejumlah bahan-bahan tertulis baik berupa: buku, artikel jurnal, dan sebagainya yang berasal dari pendapat para ahli maupun literatur yang memiliki keterkaitan dengan topik yang dibahas. 2) Wawancara, yaitu serangkaian pertanyaan yang diajukan memperoleh data dan informasi yang dibutuhkan, yaitu melaui: Wawancara Mendalam dan Wawancara Kelompok. 3) Pengambilan foto, dilakukan untuk memperkaya data yang diperoleh melalui wawancara mendalam. Pengambilan foto-foto dilakukan pada saat wawancara.

Teknik analisis data yang digunakan yaitu teknik kualitatif. Analisis data akan dilakukan secara induktif untuk mengidentifikasi realitas yang bermacam-macam di lapangan sehingga analisis menjadi lebih eksplisit, lebih nampak dan mudah dilakukan. Selain itu, analisis kualitatif secara operasional akan dilakukan melalui tiga (3) cara, yaitu: 1) Reduksi data yaitu proses pereduksian data ke dalam bentuk uraian yang lengkap dan banyak. 2) Display data yakni upaya pembuatan dan penyajian data melalui tabel sehingga keseluruhan data serta bagian-bagian detilnya dapat dipetakan dengan jelas. 3) Kesimpulan dan verifikasi, yakni penyusunan secara 
sistematis data yang sudah terkumpul, baik melalui penentuan tema maupun tabel. Selanjutnya disimpulkan sehingga dapat diperoleh makna data yang sesungguhnya.

\section{HASIL PENELITIAN DAN PEMBAHASAN \\ 1. Landscape Sosial Budaya Komunitas Pulau Tunda}

$\mathrm{P}$ ulau tunda merupakan salah satu pulau yang berada di kabupaten serang provinsi Banten, secara administratif pulau tunda terletak di Kecamatan Tirtayasa,Kabupaten Serang Provinsi Banten. Dilihat dari letak geografisnya pulau tunda terletak di koordinat $5^{\circ} 48^{\prime} 43^{\prime \prime}$ LS $106^{\circ} 16^{\prime} 47^{\prime \prime}$ BT (Profil Desa Wargasara, 2018). Secara administratif, Di Pulau Tunda terdapat satu desa atau kelurahan yaitu Desa/kelurahan Wargasara. Desa ini terdiri atas 2 dusun yakni Kampung Barat dan Kampung Timur. Secara keseluruhan kelurahan warga sara terbagi menjadi 2 (dua) Rukun Warga (RW) dan 6 (enam) Rukun Tetangga (RT), dimana Kampung Timur terdapat $1 \mathrm{RW}$ dan $4 \mathrm{RT}$, serta $1 \mathrm{RW}$ dan $2 \mathrm{RT}$ terletak dikampung Barat. Sementara untuk Luas wilayah Pulau Tunda sendiri mencapai 289.79 hektare (lihat Gambar 1). Pemukiman dan jalan Desa hanya menempat setengah bagian pulau saja yang terbentang dari bagian timur pulau hingga bagian tengah.

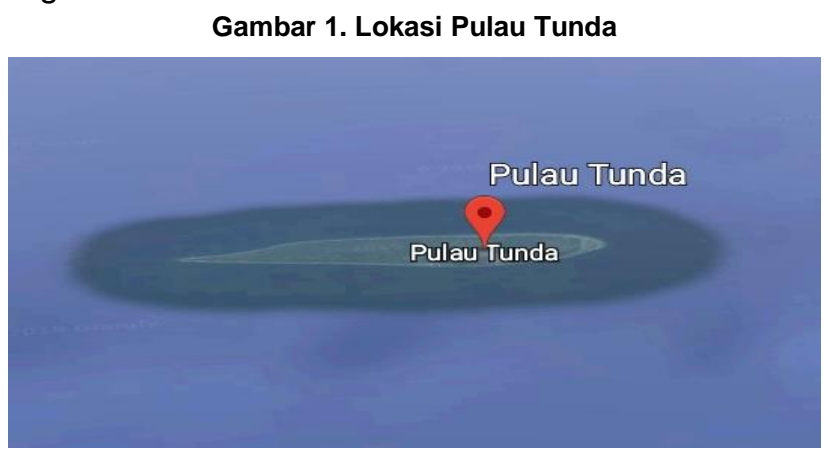

Sumber: Google Earth diolah oleh tim peneliti (2019)

Secara geologi, wilayah Pulau Tunda atau desa Wargasara merupakan pulau vulkanik yang terbentuk dari hasil endapan beku lava. Tofografi daratan Pulau Tunda datar berkisar antara (0-3 mdpl) dengan bagian imur lebih tinggi 1-2 meter dari bagian baratnya. Kondisi morfologi pantainya berpasir dan bervegetasi mangrove di bagian timur dan selatan pulau. Untuk pemanfaatan lahan di Pulau Tunda di dominasi oleh semak belukar, hanya sekitar 10 hektar lahan yang dijadikan area untuk perumahan dan fasilitas umum. Dalam jumlah terbatas, secara tradisional lahan penduduk juga dimanfaatkan untuk hortikultura seperti cabai serta tanaman perkebunan seperti kelapa, sukun, jambu dan sebagainya, warga juga mengembangkan pembesaran pohon kayu jenis albasiah (sengon).

Selanjutnya Pulau Tunda merupakan pulau yang ditempati lebih 1.115 jiwa penduduk dengan jumlah kepala keluarga sebanyak 364 Kepala Keluarga (KK). Warga di 2 (dua) kampung ini di pimpin oleh ketua RW \& RT dengan kantor pusat pemerintahan desa yang terletak dipinggir laut dekat pelabuhan. Selain itu, keterbatasan energi listrik di Pulau Tunda masih terbatas, hanya tersedia dari pukul 18.00 s.d 21.00 WIB untuk Pembangkit Listrik Tenaga Diesel (PLTD) dan pukul 21.00 s.d 02.00 untuk Pembangkit Listrik Tenaga Surya (PLTS). Akses jaringan internet di Pulau Tunda masih sulit didapatkan, sinyal bisa dijangkau hanya pada tempat-tempat tertentu, salah-satunya di dermaga Pantai Timur, kantor Kepala Desa, area jembatan galau di Pantai utara dan Pantai Timur. Mereka hidup dalam kondisi seperti ini sudah sejak lama dialami, yang mereka sebagian besar merupakan penduduk yang hidup turun-temurun di daerah tersebut, dimana menurut warga sekitar nenek moyang mereka berasal dari daerah pantai utara wilayah Serang terutama dari kecamatan pontang, Kabupaten Serang.

Penduduk Pulau Tunda memiliki mata pencaharian sebagai nelayan, buruh tani, pedagang, wiraswasta, tukang, dan Pegawai Negeri Sipil (PNS) dengan persentase: nelayan $80 \%$, buruh tani $10 \%$, dan yang lainnya sekitar $10 \%$. Selanjutnya, berdasarkan keterangan informan, diketahui bahwa anak muda Pulau Tunda banyak yang menganggur. Mayoritas pekerjaan masyarakat Pulau Tunda adalah nelayan dan petani. Namun tidak sedikit yang beralih profesi pada sektor wisata dan usaha untuk menambah penghasilan guna membantu perekonomian keluarga. Data Kecamatan Tirtayasa dalam Angka (2016) mencatat dari sisi kesejahteraan ekonominya, $200 \mathrm{KK}$ diantaranya masuk dalam kelompok prasejahtera dan sejahtera 1, sehingga apabila dihubungkan antara mata pencaharian dan kondisi kesejahteraan ekonominya dapat ditemukan bahwa mata pencaharian penduduk sebagai nelayan di wilayah tersebut belum memberikan kesejahteraan yang cukup bagi keluarga yang ditanggungnya.

Selanjutnya, masyarakat di Pulau Tunda sudah memiliki modal sosial sosial yang kuat, dimana sebagai masyarakat pulau/pedesaan mereka memiliki norma dan hubungan sosial yang menyatu dalam struktur masyarakat dan membuat semua warga dapat bekerjasama dalam bertindak untuk mencapai tujuan. Dengan sektor mata pencaharian yang terbatas, mereka memiliki aksi bersama atau kerjasama dalam 
membangun ekonominya yang mampu menopang kesejahteraan keluarganya, melalui aksi mengembangkan wisata sebagai alternatif nafkah. Pola ini sudah berlangsung beberapa tahun terakhir yang dibangun melalui modal sosial dalam masyarakat.

Konsep modal sosial Syafar (2017: 5) menyebut sebagai seperangkat nilai-nilai, norma, dan kepercayaan yang mempermudah masyarakat bekerja sama secara aktif dan terkoordinasi untuk mencapai tujuan-tujuannya. Secara sosial, komunitas Pulau Tunda masih memegang tradisi dalam menjaga alam dan lingkungannya untuk keberlanjutan penghidupannya di masa kini dan yang akan datang. Untuk itu, pengembangan ekowisata di Pulau Tunda tidak bisa dilepaskan daari modal sosial komunitas yang secara manfaat memberikan dampak sosial ekonomi wilayahnya.

\section{Pengembangan Ekowisata Melalui Peman faatan Teknologi Digital}

Upaya penguatan sosial ekonomi oleh komunitas Pulau Tunda dalam pengembangan ekowisata di era milenial membutuhkan dukungan teknologi informasi. Ekowisata yang dibangun oleh komunitas perlu sejalan dengan era industri 4.0 dalam meningkatkan usaha ekonomi lokal, dimana menurut Marsudi (2019) menyebut revolusi industri 4.0 menggambarkan realisasi dari Internet of Things dalam konteks pabrikasi untuk merealisasikan kemampuan fleksibilitas dan kemampuan beradaptasi yang tinggi dari sistem produksi. Dengan demikian, keberadaan webiste bagi pengembangan ekowisata berbasis komunitas di pulau Tunda sangat penting dalam menjalankan aktivitas industri bisnis wisata, yang utamanya berfungsi sebagai sarana promosi bagi kemajuan ekowisata tersebut.

Dengan melesatnya nama Pulau Tunda sebagai salah satu destinasi wisata di Provinsi Banten, para pemuda mulai menggerakkan usaha ini secara bersama-sama dalam naungan Pokdarwis, mereka menjadikan Pulau Tunda sebagai desain pilihan wisata yang menarik bagi wisatawan.

Keindahan biota bawah laut Pulau Tunda menjadi hal yang dicari oleh wisatawan. Hasil wawancara mencatat bahwa Pokdarwis ini awalnya dibentuk karna rasa kebersamaan sekelomok warga pulau tunda yang peduli terhadap kesenjangan yang terjadi pada masyarakat. Hingga dibentuklah suatu komunitas yang fungsinya mengenalkan dan mengembangkan Pulau Tunda sebagai objek pariwisata bahari dengan branding Ekowisata, dimana Pokdarwis ini di jadikan plattform khusus untuk menggerakan masyarakat
Pulau Tunda terlibat dalam upaya-upaya pengembangan wilayah pariwisata berbasis komunitas dengan mengusung tujuan terciptanya wilayah pariwisata Sapta Pesona (ketertiban, keamanan, keindahan, kebersihan, keramahan dan kenangan) dengan menyajikan ekosistem yang unik dan lengkap, sekeliling pulau mengenalkan taman mangrove, lamun dan terumbu karang yang ketiganya saling mendukung membentuk suatu ekowisata yang sangat unik.

Selanjutnya, upaya Pokdarwis dalam menciptakan peluang ekowisata di era industri 4.0 merupakan syarat penting dilakukan melalui digitaliasi berbasis internet. Upaya ini bisa dilakukan melalui penyediaan website khusus bagi Pulau Tunda, namun memiliki keterbatasan akses mulai dari listrik, internet, dan sarana prasarana lainnya. Kegiatan ekowisata ini memiliki peluang untuk memperoleh keuntungan yang diwujudkan oleh masyarakat melalui peningkatan layanan wisata dengan melengkapi kebutuhan pengunjung/wisatwan, seperti guest house dan pengembangan sarana akomodasi lainnya (Miswanto \& Safaat, 2018: 49). Sejalan dengan upaya tersebut, Mba (2020: 205) menyebut bahwa peningkatan pelayanan wisata seperti di desa Liang Ndara diarahkan pada Lembaga Ekowisa Riang Tana Tiwa yang menjadi pelopor karena mampu menangkap peluang keuntungan finansial sekaligus melestarikan budaya dan ekologi.

Dalam catatan lapangan ditemukan bahwa di Pulau Tunda terbatas pada akses informasi yang berbeda seperti penduduk di darat karena keterbatasan koneksi internet yang menghubungkan mereka untuk berkomunikasi jadi tidak semua dapat mengerti tentang internet, sosial media, apalagi bisnis online hanya ada salah satu dari warga sana yang sebagian mengerti tentang internet. Yang paham tentang sosial media umumnya para pemuda, sedangkang generasi orang tuanya terbatas soal perkembangan teknologi ini.

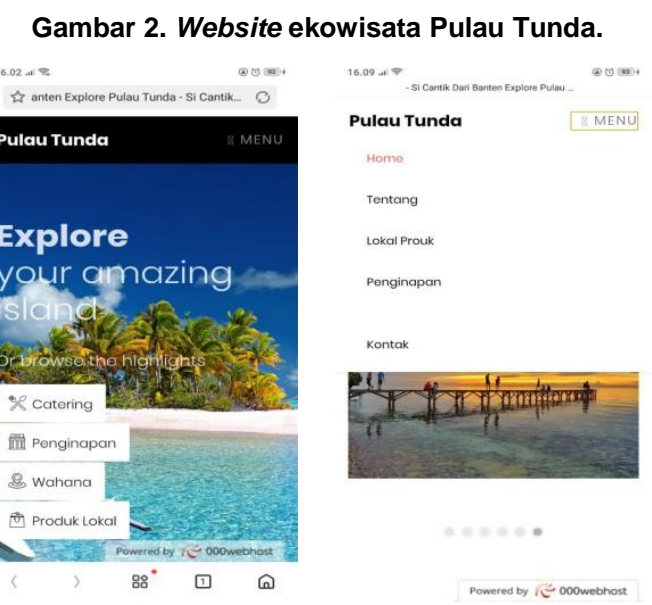

Sumber: dokumentasi tim peneliti (2019)

$122 \mid \mathrm{P}$ a g e https://doi.org/10.25077/jantro.v23.n1.p118-128.2021 
Menurut Pokdarwis, program ekowisata yang menggunakan sarana teknologi informasi, sangat berguna dan mereka menyadari pentingnya sosial marketing di era globalisasi saat ini. Sebab era ini menuntut adanya kemajuan teknologi di berbagai bidang khusunya pariwisata. Program ini sudah difasilitasi oleh Jurusan Pengembangan Masyarakat Islam (PMI), Fakultas Dakwah-UIN Sultan Maulana Hasanuddin Banten yang merupakan inisiasi bersama dalam bentuk fasilitasi untuk mempromosikan Pulau Tunda sendiri dan juga produk-produk lokal yang ingin dipasarkan oleh masyarakat (lihat Gambar 2). Konten yang sudah diposting di website tersebut terdiri dari: homestay, produk lokal, transportasi, dan paket wisata (snorkling, mancing, diving, dan sebagainya).

Konsep promosi menurut Basu Swastha dalam Wolah (2016: 2) dijelaskan bahwa promosi merupakan insentif jangka pendek untuk mendorong pembelian atau penjualan dari suatu prodak atau jasa. Keberadaan website bisa memberikan informasi yang spesifik dan manfaatnya bisa diakses oleh publik terkait dengan ekowisata yang dikembangkan oleh komunitas. Ekowisata berbasis masyarakat dilakukan sebagai usaha wisata yang bertumpu pada peran aktif masyarakat. Disinilah letak urgensi pemberdayaan yang menurut Sujarwani, dkk. (2018: 22) menyebut suatu program pemberdayaan dalam konteks pembangunan masyarakat perlu bertumpu pada landasan filosofisnya, yakni programa pembangunan itu memberikan dampak positif kepada semua pihak, diantaranya: komunitas sasaran dan stakeholders.

Untuk mengoperasikan website, peran pemuda sebagai generasi milenial sangat penting, dikarenakan saat ini dunia internet sudah menjadi kebutuhan generasi milenial, sehingga proses promosi bisa dijalankan. Hal tersebut didasarkan kepada kenyataan bahwa masyarakat memiliki pengetahuan tentang alam serta budaya yang menjadi potensi dan nilai jual sebagai daya tarik wisata, sehingga pelibatan masyarakat menjadi mutlak. Pola ekowisata berbasis masyarakat mengakui hak masyarakat lokal dalam mengelola kegiatan wisata di kawasan yang mereka miliki secara adat ataupun sebagai pengelola. Dengan adanya pola ekowisata berbasis masyarakat bukan berarti masyarakat akan menjalankan usaha ekowisata sendiri.

Era industri 4.0 yang hadir pada generasi millenial sekarang ini, ternyata mulai dikembangkan secara serius sejak media sosial semakin menyemarakkan dunia internet seperti Facebook, Twitter, Line, dan Instagram. Para pengguna internet tidak saja sebagai konsumen data yang tersedia, melainkan merupakan produser data itu sendiri. Jadi Pokdarwis dalam mengembangkan ekowisata memiliki potensi untuk memasarkan Pulau Tunda melalui berbagai saluran media internet, yaitu website. Bagi Pokdarwis yang sedang melakukan upaya bisnis ekowisata, saluran ini sangat besar dan dapat dimanfaatkan untuk menghasilkan suatu pola atau bentuk yang menghasilkan suatu pengetahuan baru bagi publik yang ingin berkunjung ke Pulau Tunda. Secara umum, Pokdarwis menganggap bahwa dengan adanya akses internet ini akan menciptakan usaha yang dikembangkan komunitas akan menciptakan volume pengunjung yang besar (volume), pertumbuhan permintaan yang pesat (velocity), bentuk berbagai format pelayanan yang sesuai kebutuhan pelanggan (variety), nilai kelestarian ekosistem yang dapat dimanfaatkan (value), pelayanan yang valid dan menyenangkan bagi pelanggan (veracity). Untuk itu, keberadaan akses teknologi informasi ini bagi Pokdarwis akan semakin menarik bagi pengembangan usahanya manakala dapat dimanfaatkan dan berguna untuk kepentingan kemajuan komunitas di Pulau Tunda.

Pokdarwis Pulau Tunda sebagai kelompok bisnis yang bergerak dalam bidang ekowisata di wilayahnya, bisa bertugas sebagai penggerak sadar wisata dan sapta pesona di Pulau Tunda melalui sarana internet. Tentunya perlu ada peningkatan kompetensi SDM guna memperbaiki kualitas pelayanan terhadap wisatawan terutama, akases wisatawan untuk mengenal Pulau Tunda dan pelayanan yang umumnya menjadi skala prioritas dalam wisata yang ditawarkan. Sebagaimana diperlihatkan pada Gambar 3 di bawah ini.

Gambar 3. Area Snorkeling dan Diving di Pulau Tunda

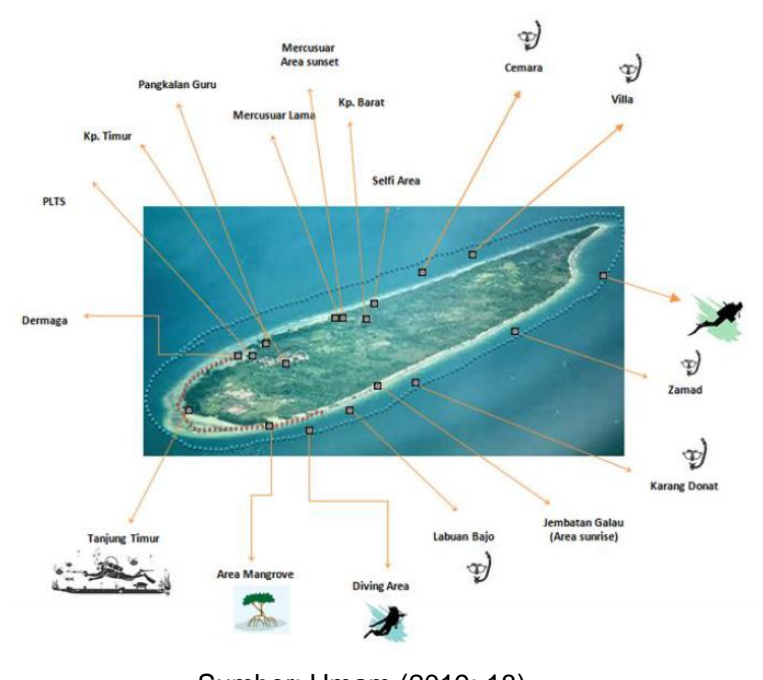

Sumber: Umam (2019: 18) 
Selanjutnya, dalam aplikasi internet tersebut, Pokdarwis sudah bisa menyediakan sarana untuk menunjang fasilitas wisatawan dimana beberapa warga lokal sudah menyediakan homestay, sekitar 20 unit. Besaran harga yang ditetapkan untuk menginap sekitar Rp. 200.000,- hingga Rp. 400.000,- ribu yang dengan fasilitas sederhana untuk 10-15 orang/unit dan cukup untuk tidur dan mandi bagi wisatawan. Begitu juga dengan sarana transportasi yang bisa diakses oleh wisatawan melalui website maupun social media, hal ini untuk menunjang transportasi yang hanya bisa menggunakan kapal kayu, bisa Kapal Reguler maupun sewa kapal milik warga lokal maupun agen travel.

Berbagai manfaat akses internet yang digunakan oleh komunitas ekowisata di Pulau Tunda ternyata memiliki keuntungan bagi mereka yang menerapkannya sebagai aspek komunikasi pemasaran. Komunikasi melalui media internet memiliki pengaruh pada pemasaran ekowisata Pulau Tunda yang dikembangkan oleh Pokdarwis. Keberadaan internet sebagai sarana komunikasi ini terus dikembangkan oleh komunitas dalam menjaring wisatawan dari luar pulau. Dalam catatan lapangan dituliskan bahwa Pokdarwis saat ini menganggap komunikasi melalui media digital dan internet merupakan cara yang efektif dalam memasarkan produk ekowisata di Pulau Tunda, cara yang dilakukan saat ini adalah melalui proses penyebaran informasi tentang ekowisata dan apa yang hendak ditawarkannya (offering) pada wisatawan melalui media daring (website dan media sosial). Pokdarwis mempromosikan potensi ekowisata dengan menekankan Pulau Tunda sebagai salah satu daya tarik wisata bagi wisatawan. Jika dilihat dari aktivitas wisata, pengunjung banyak yang datang di akhir pekan (Sabtu atau Minggu) dan mereka menikmati paket wisata di laut lepas Selat Sunda. Banyak dari mereka yang ingin mencoba snorkeling dan diving (lihat Gambar 2) pada titik lokasi yang sudah ditentukan oleh Pokdarwis, yaitu: Zamad, Karang Donat, Labuan Bajo, Cemara dan Villa. Jadi, keberadaan sarana komunikasi melalui website dan media sosial menjadi faktor pendukung keberhasilan program Pokdarwis, yaitu pengembangan ekowisata berbasis komunitas.

Era revolusi industri 4.0 telah hadir di hadapan publik. Era ini akan meninggalkan pola lama dalam proses bisnis yang mengedepan kan efisiensi dan afektifitas. Komunitas di Pulau Tunda sudah mulai memikirkan peran internet sebagai media promosi yang paling jitu dalam menjangkau kebutuhan dan keinginan publik untuk bisa menikmati fasilitas ekowisata di wilayahnya. Dalam Natasuwarna (2019: 23) menyebut bahwa era industri 4.0 telah memunculkan peluang industri baru yang melayani konsumen lebih baik dengan menyediakan kecepatan pelayanan, fleksibiltas produksi, dan ditemukannya metoda menurunkan kegagalan produksi. Untuk itu, keberadaan website menjadi pembuka jalan bagi komunitas dikenal oleh publik.

Aktifitas bisnis di era ini sudah cenderung mengalami perubahan yang begitu cepat. Berbagai kalangan menilai bahwa era ini memberikan pengaruh yang efektif dan efisien dalam menggunakan fasilitas teknologi informasi dalam skala yang luas. Hal ini dapat dilihat dari kecenderungan publik merasa senang menggunakan ojek online, dengan biaya yang murah dan pelayanan yang baik. Selain itu, pola jual beli online sudah mulai digemari publik yang secara manfaat berkontribusi bagi kenyamanan berbisnis yang efisien.

Keberadaan website dan media sosial yang digunakan oleh Pokdarwis memiliki implikasi bagi komunitas di Pulau Tunda. Bukan hanya pada kelompok pemuda sebagai penggerak ekowisata, namun juga masyarakat secara umum memperoleh manfaat ekonomi. Penyediaan jasa homestay, paket kuliner dan cinderamata yang mereka kembangkan, ternyata banyak dilirik oleh wisatawan. Walaupun saat ini manfaat ekonominya masih terbatas, namun sajian pelayanan yang diberikan oleh komunitas kepada wisatawan tetap berjalan baik. Hal ini disebabkan komunitas saat ini telah memahami bahwa unsur pembentuk pengalaman perjalanan wisatawan adalah daya tarik yang dimiliki oleh suatu tempat atau lokasi yang menjadi tujuan wisata. Sebagaimana dikemukakan oleh tokoh masyarakat bahwa untuk dapat meningkatkan taraf hidup masyarakat pulau yang sejahtera di perlukan segala bentuk fasilitas pendukung yang memadai terciptanya kesejahteraan. Berikut adalah kutipan wawancara yang dilakukan :

"Masyarakat pulau tunda mayoritas kan
pekerjaannya sebagai nelayan, tapi
penghasilan harian sebagai nelayan bagi
kebanyakan masyarakat tidak cukup untuk
memenuhi kebutuhan hidup, karena itulah
masyarakat pulau tunda yang punya
potensi pariwisata terumbu karang (lihat:
Gambar 4) yang bagus harus dimanfaatkan
sebagai upaya untuk membantu
perekonomian masyarakat secara
langsung" (HSM, kampung timur 21
Agustus 2019)

Atas dasar penjelasan di atas, Pulau Tunda yang lokasinya tidak jauh dari kota Serang sebenarnya menjadi peluang bagi pengembangan ekowisata yang digeluti oleh komunitas. Peluang ini juga sangat diakui oleh Pokdarwis, pemerintah, perguruan tinggi serta 
pelaku usaha lainnya. Semua pihak menilai, jika ekowisata ini dikemas dengan baik melalui promosi digital era industri 4.0 yang berkelanjutan, maka jarak Pulau Tunda bagi wisatawan yang tidak menjadi tantangan, bahkan bisa memberikan nilai manfaat bagi komunitas di Pulau Tinda. Saat ini, permintaan pasar wisata telah meningkat dan menyebar secara luas, dan jika dikelola dengan baik akan meningkatkan daya tarik dan memenuhi kebutuhannya. Sehingga ini menjadi peluang bagi komunitas agar mewujudkan kehidupan mereka yang lebih baik. Keindahan alam dan kearifan lokal yang ada Pulau Tunda, merupakan asset komunitas yang perlu dijaga dan secara potensial menambah nilai kelestarian ekowisata, misalnya keunggulan pengelolaan tanaman mangrove dan hortikultura. Dengan demikian, promosi sangat perlu dilakukan secara berkelanjutan sebagai salah satu strategi yang akan menjadi daya tarik wisatawan untuk datang ke Pulau Tunda.

\section{Gambar 4. Terumbu karang Pulau Tunda}

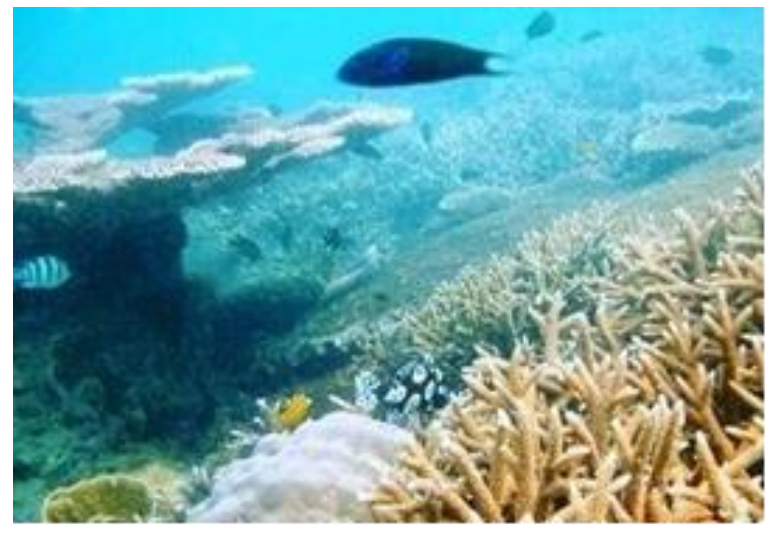

Sumber: dokumentasi tim peneliti (2019)

Era otonomi desa yang saat ini sejalan dengan pencapaian Sustainability Development Goals (SDGs) tahun 2030 dalam arah pengembangan proses desentralisasi pembangunan di dalamnya terkandung tujuan menciptakan pembangunan berdasarkan prakarsa masyarakat. Kemampuan desa Wargasara (Pulau Tunda) dalam melaksanakan tujuan pembangunan tersebut perlu terus ditingkatkan melalui pendekatan strategi, dengan perencanaan dan pelaksanaan pembangunan yang lebih terarah dan optimal melalui ekowisata. Dengan demikian, jelas bahwa pengembangan ekowisata yang bertumpu pada modal sosial komunitas dan kearifan lokalnya akan mewujudkan kawasan tersebut memiliki manfaat secara sosial ekonomi. Modal sosial ini sebagai potensi penunjang kehidupan bagi komunitas yang tercermin dari pemanfaatan fungsi sumberdaya dan kearifan lokalnya yang terus berkembang dan berkelanjutan untuk masa depan generasi selanjutnya. Besar atau kecilnya, maupun tinggi atau rendahnya tingkat perkembangan tersebut sangat tergantung pada faktor-faktor perkembangan, yang meliputi aspek fisik, demografi dan sosial-budaya, ekonomi, dan kelembagaan yang bertumpu pada modal sosial dan kearifan lokanya untuk selalu menjaga sumberdaya alam sebagai potensi unggulan komunitas lokal.

\section{Manfaat Teknologi Digital Bagi Pengembangan Ekowisata}

Penjelasan di atas menggambarkan bahwa Pulau Tunda sebagai kawasan ekowisata kepulauan, perkembangannya perlu mengintegrasikan pengembangannya dengan modal sosial dan kearifan lokal yang dimilikinya. Hal ini penting, sebab menurut Syafar (2016) menyebutkan menyebut modal sosial sebagai seperangkat nilai-nilai, norma, dan kepercayaan yang mempermudah masyarakat bekerja sama secara aktif dan terkoordinasi untuk mencapai tujuan-tujuannya. Perkembangan Pulau Tunda yang hanya fokus pada komersialisasi ekowisata dari produk yang dihasilkan, struktur pasar serta penyebaran sarana dan prasarana yang tidak memperhatikan kearifan lokalnya, maka akan menjadikan wilayah tersebut tidak dapat memiliki surplus manfaat sosial ekonominya, dan kecenderungannya akan menurunkan kualitas hidup komunitas Pulau Tunda. Untuk itu, jika komunitas ingin tetap mengembangkan ekowisatanya, maka secara sosial, komunitas Pulau Tunda terus memegang tradisi dalam menjaga alam dan lingkungannya dalam mempertahankan keberlanjutan penghidupannya di masa kini dan yang akan datang. Dengan demikian, pengembangan ekowisata di Pulau Tunda tidak bisa dilepaskan daari modal sosial komunitas yang secara manfaat memberikan dampak sosial ekonomi wilayahnya.

Ekowisata Pulau Tunda yang dikembangkan berbasis komunitas merupakan usaha yang berkelanjutan yang menitikberatkan peran aktif warga lokal untuk mengelolanya ke arah yang lebih baik. Hal tersebut dilihat dari realitas bahwa komunitas memiliki pengetahuan dan keterampilan mengelola alam serta modal sosialnya yang menjadi potensi dan peluang serta memiliki nilai jual daya tarik wisata yang bertumpu pada perkembangan teknologi informasi di era industri 4.0 dalam kerangka millenial. Keterlibatan komunitas mutlak memegang peran penting dala mengelola dan melestarikan pola ekowisata yang dikembangkan. 
Keberadaan website yang telah eksis hari ini, merupakan modal/aset yang terus dijaga keberlanjutannya. Komunitas lokal mengelola kegiatan ekowisata di kawasan Pulau Tunda yang secara adat sebagai sumber penghidupannya. Dengan adanya pola ekowisata yag bertumpu pada kekuatan lokal dan global, komunitas sudah mulai terbuka dan profesional dalam pengelolaannya untuk mencapai tujuan yang efektif dan efisien. Sehingga tujuan ini sejalan dengan agenda pemerintah dalam mencapai SDGs 2030, yang tertuang dalam Peraturan Menteri Dalam Negeri Nomor 33 Tahun 2009 bahwa prinsip pengembangan ekowisata, meliputi: (1) kesesuaian antara jenis dan karakteristik ekowisata; (2) konservasi; (3) ekonomis; (4) edukasi; (5) memberikan kepuasan dan pengalaman kepada pengunjung; (6) partisipasi masyarakat; dan (7) menampung kearifan lokal.

Salah satu tantangan yang dihadapi komunitas terkait dengan pengelolaan ekowisata sesuai dengan perkembangan teknologi informasi dan ilmu pengetahuan adalah tingkat kompetensi maupun keterampilannya yang dihadapkan dengan persaingan dunia usaha wisata untuk mencapai eksistensi penghidupan komunitas lokal. Pengembangan website dengan berbagai inovasinya sangat penting dan perlu digalakkan oleh komunitas, salah satunya adalah untuk memasarkan ekowisata yang dipromosikan komunitas. Pengelolaan website maupun social media dalam mempromosikan Pulau Tunda yang berkelanjutan dengan semangat nilai-nilai kearifan lokal akan menciptakan peluang usaha menjadi meningkat, karena dikelola oleh insan yang memiliki ketrampilan teknologi maupun ketrampilan bisnis untuk melakukan pemberdayaan masyarakat. Sehingga pengembangan ekowisata akan terwujud dalam pengelolaan SDM yang berkualitas dan handal.

Tantangan ke depan yang dihadapi komunitas yaitu keberadaan jaringan komunikasi yang ada di Pulau Tunda yang masih terbatas. Dari beberapa provider telekomunikasi, Indosat merupakan jaringan yang relatif stabil, baik GSM, 3G, HSDPA maupun 4G. Untuk itu, jika komunitas ingin memiliki target pencapaian tujuan yang diharapkan, maka membangun kolaborasi itu sangat penting dengan berbagai pihak, diantaranya: pemerintah, provider telekomunikasi, dan Perusahaan Listrik Negara (PLN).

Berbagai penjelasan di atas menyebutkan bahwa potensi Pulau Tunda memiliki objek ekwisata yang menawarkan berbagai keindahan alam dan juga modal sosial kehidupan masyarakatnya. Potensi ini menjadi peluang pengembangan ekowisata, diantaranya: 1) Pasar wisata yang dapat menjangkau wisatawan secara luas, 2) kebutuhan wisatawan menikmati jasa ekowisata yang semakin meningkat, dan 3) lokasi
Pulau Tunda yang relatif tidak jauh dari pusat kota dengan melintasi laut sekitar 2 jam perjalanan. Dengan demikian, potensi dan peluang tersebut mengindikasikan bahwa wisatawan akan banyak menerima manfaat dari pelayanan yang ditawarkan ketika berwisata di Pulau Tunda.

Tidak hanya itu, keberadaan website \& social media yang terus digalakkan tersebut juga memiliki manfaat yang diterima oleh wisatawan. Berbagai produk ekowisata yang dipromosikan melalui internet tersebut merupakan kekuatan komunitas untuk terus menjaga permintaan dan kebutuhan wisatawan. Untuk itu, upaya mengawal industri wisata berbasis teknologi informasi secara berkelanjutan akan memberikan manfaat bagi semua pihak, sehingga hal yang perlu tetap dipertahankan oleh komunitas yaitu: 1) Meningkatkan penyebaran informasi melalui internet, 2) membuat icon-icon wisata yang sesuai dengan kearifan lokalnya, dan 3) menambah produk wisata di daratan dan lautan.

Manfaat keberadaan akses internet yang telah ada dan dikembangkan komunitas ekowisata di Pulau Tunda ternyata, ternyata memberikan dampak secara luas. Komunikasi yang digencarkan melalui internet (website dan social media) memiliki pengaruh pada promosi ekowisata Pulau Tunda. Pokdarwis mempromosikan potensi ekowisata dengan menekankan Pulau Tunda sebagai salah satu daya tarik wisata bagi wisatawan. Jika dilihat dari aktivitas wisata, pengunjung banyak yang datang di akhir pekan (Sabtu atau Minggu) dan mereka menikmati paket wisata di laut lepas Selat Sunda. Internet telah memberi manfaat sebagai sarana komunikasi ini terus dikembangkan oleh komunitas dalam menjaring wisatawan dari luar pulau.

Sebagaimana telah dijelaskan bahwa Pokdarwis saat ini menganggap komunikasi melalui media digital dan internet merupakan cara yang efektif dalam memasarkan produk ekowisata di Pulau Tunda, cara yang dilakukan saat ini adalah melalui proses penyebaran informasi tentang ekowisata dan apa yang hendak ditawarkannya (offering) pada wisatawan melalui media daring (website dan media sosial). Banyak dari mereka yang ingin mencoba snorkeling dan diving di beberapa titik lokasi yang sudah ditentukan, yaitu: Zamad, Karang Donat, Labuan Bajo, Cemara dan Villa. Jadi, keberadaan sarana komunikasi melalui website dan media sosial memiliki korelasi sebagai faktor pendukung keberhasilan program Pokdarwis, yaitu pengembangan ekowisata berbasis komunitas. 


\section{KESIMPULAN}

tudi ini menghasilkan temuan terpenting dalam pengelolaan dan pengembangan ekowisata berbasis komunitas di Pulau Tunda dalam era industry 4.0 yang selama ini dijadikan sumber mata pencaharian penduduk lokal. Pengembangan ekowisata di Pulau Tunda tidak bisa dilepaskan daari modal sosial komunitas yang secara manfaat memberikan dampak sosial ekonomi wilayahnya. Komunitas hingga kini tetap mengembangkan ekowisatanya yang secara sosial memegang tradisi dalam menjaga alam dan lingkungannya untuk mempertahankan keberlanjutan penghidupannya di masa kini dan yang akan datang.

Komunitas ekowisata Pulau Tunda memiliki pengetahuan dan keterampilan mengelola alam serta modal sosialnya yang bertumpu pada perkembangan teknologi informasi di era industri 4.0 dalam kerangka millenial. Keberadaan website yang telah eksis hari ini, merupakan modal/aset yang terus dijaga keberlanjutannya, sehingga akan mencapai tujuan komunitas sejalan dengan agenda SDGs 2030. Terakhir, pengelolaan ekowisata oleh komunitas bertumpu pada teknologi digital, ternyata meberikan manfaat secara luas. Komunikasi yang digencarkan melalui internet (website dan social media) memiliki pengaruh pada promosi ekowisata Pulau Tunda.
Pokdarwis mempromosikan potensi ekowisata dengan menekankan Pulau Tunda sebagai salah satu daya tarik wisata bagi wisatawan. Pokdarwis saat ini menerapkan berbagai cara yang efektif dalam memasarkan produk ekowisata di Pulau Tunda, yaitu: snorkeling dan diving di beberapa titik lokasi yang sudah ditentukan, yaitu: Zamad, Karang Donat, Labuan Bajo, Cemara dan Villa.

\section{E. UCAPAN TERIMA KASIH}

$\mathrm{K}$ ami mengucapkan terima kasih kepada Kementerian Agama RI yang telah memberi kami peluang melaksanakan riset ini melalui program Competitive Community Service Grant on the Title Coastal Community Assistance in Tunda Island, Serang-Banten, Indonesia. Kemudian kepada Prof. Fauzul Iman, selaku Rektor UIN Sultan Maulana Hasanuddin Banten, Lembaga Penelitian dan Pengabdian kepada Masyarakat (LP2M) yang telah mendorong kami dalam melaksanakan riset ini di Pulau Tunda, serta para mahasiswa kami selaku asisten lapangan yang telah membantu dalam pengumpulan data yang relevan.

\section{DAFTAR PUSTAKA}

Darus, Robba Fahrisy, Dedi, Juraij, Syahrial, Dea Fauzia Lestari, Aditya Hikmat Nugraha, N. P. Z. (2014). Keanekaragaman Hayati Ekosistem Pesisir di Pulau Tunda, Kabupaten Serang, Banten. Seminar Nasional Kelautan: Pengelolaan Sumber Daya Kelautan Dan Perikanan Wilayah Pesisir Dan PulauPulau Kecil Berkelanjutan Melalui Kedaulatan Maritim, 53(9), 1689-1699.

Djamba, Y. K., \& Neuman, W. L. (2002). Social Research Methods: Qualitative and Quantitative Approaches. Teaching Sociology, 30(3), 380. https://doi.org/10.2307/3211488

Hijriati, E., \& Mardiana, R. (2015). Pengaruh Ekowisata Berbasis Masyarakat terhadap Perubahan Kondisi Ekologi, Sosial dan Ekonomi di Kampung Batusuhunan, Sukabumi. Sodality: Jurnal Sosiologi Pedesaan, 2(3). https://doi.org/10.22500/sodality.v2i3.9422

Kuswara, K. (2013). Daya Dukung Lahan untuk Pengembangan Perumahan Di Pulau Panggang, Pulau Pramuka, Pulau Kelapa dan Pulau Tunda. Jurnal Permukiman, 8(1), 24-29. Retrieved from http://jurnalpermukiman.pu.go.id/index.php/JP/article/download/95/82

Marsudi, A. S., \& Widjaja, Y. (2019). Industri 4.0 dan Dampaknya Terhadap Financial Technology serta Kesiapan Tenaga Kerja di Indonesia. Ikraith Ekonomika, 2(2), 1-10.

Mba, D. A. (2020). Ekowisata sebagai Bentuk Adaptasi Masyarakat Liang Ndara pada Pariwisata. Jurnal Antropologi: Isu-Isu Sosial Budaya, 22(2), 198-207. https://doi.org/10.25077/jantro.v22.n2.p198207.2020

Miswanto, M., \& Safaat, M. (2018). DAMPAK PEMBANGUNAN INDUSTRI PARIWISATA TERHADAP ALIH FUNGSI LAHAN. Jurnal Antropologi: Isu-Isu Sosial Budaya, 20(1), 45-55. https://doi.org/10.25077/jantro.v20.n1.p45-55.2018

Natasuwarna, A. P. (2019). Tantangan Menghadapi Era Revolusi 4.0 (Big Data dan Data Mining). Seminar Nasional Hasil Pengabdian Kepada Masyarakat (Sindimas) 2019, 23-27.

Neuman, W. L. (2003). Social Research Methods: Qualitative and Quantitative Approaches. USA: Allyn and Bacon.

Pemerintah Desa Wargasara. (2018). Profil Desa Wargasara: Pulau Tunda. Serang.

Pemerintah Kecamatan Tirtayasa. (2016). Tirtayasa dalam Angka. Serang.

Sugiyono. (2008). Penelitian Kuantitatif, Kualitatif dan R \& D. Bandung: Penerbit Alfabeta. 
Sujarwani, R., Wulandari, F. D., Husni, A., Rianto, F., \& Sarinah. (2018). PEMBERDAYAAN MASYARAKAT KOMUNITAS ADAT TERPENCIL (KAT) OLEH PEMERINTAH KABUPATEN LINGGA. Jurnal Antropologi: Isu-Isu Sosial Budaya, 20(1), 17-31. https://doi.org/10.25077/jantro.v20.n1.p17-31.2018

Sulistian, A. (2016). Pulau Tunda sebagai Daerah Tujuan Wisata Bahari Kabupaten Serang. Skripsi pada Program Studi IImu Komunikasi, FISIP, Universitas Sultan Ageng Tirtayasa-Banten.

Syafar, M. (2016). Memahami Penerapan dan Manfaat Teori Sistem, Life-Span, Interaksi Simbolis, Pertukaran Sosial pada Masalah Sosial. Lembaran Masyarakat, II(1), 1-28. Retrieved from http://jurnal.uinbanten.ac.id/index.php/lembaran/article/view/479/415

Syafar, M. (2017). Modal Sosial Komunitas dalam Pembangunan Sosial. Lembaran Masyarakat, III(1), 1-22. Retrieved from http://jurnal.uinbanten.ac.id/index.php/lembaran/article/view/530/457

Syahrial, S., \& Sastriawan, Y. (2018). Pola Sebaran, Indikator Kualitas Lingkungan dan Ekologi Komunitas Mangrove Pulau Tunda. SAINTEK PERIKANAN: Indonesian Journal of Fisheries Science and Technology. https://doi.org/10.14710/ijfst.14.1.43-51

Umam, C. (2019). Strategi Pengembangan Ekowisata Bahari di Pulau Tunda. Jurnalis, 2(1), 13-22. Retrieved from http://ejournal.lppm-unbaja.ac.id/index.php/jls/article/download/528/243

Wolah, F. F. C. (2016). Peranan Promosi dalam Meningkatkan Kunjungan Wisatawan di Kabupaten Poso. Acta Diurna, 5(2). Retrieved from https://ejournal.unsrat.ac.id/index.php/actadiurnakomunikasi/ article/view/11722

Zamani, N. P. (2016). Kondisi Terumbu Karang dan Asosiasinya dengan Bintang Laut di Perairan Pulau Tunda, Kabupaten Serang, Provinsi Banten. Jurnal Teknologi Perikanan Dan Kelautan. https://doi.org/10.24319/jtpk.6.1-10 